\title{
What the Iberian Conquest Bequeathed to Us: The Fruit Trees Introduced in Argentine Subtropic-Their History and Importance in Present Traditional Medicine
}

\author{
Pablo C. Stampella, ${ }^{1,2}$ Daniela Alejandra Lambaré,,3 \\ Norma I. Hilgert, ${ }^{2,4}$ and María Lelia Pochettino ${ }^{1,2}$ \\ ${ }^{1}$ Laboratorio de Etnobotánica y Botánica Aplicada, Facultad de Ciencias Naturales y Museo, Universidad Nacional de La Plata, \\ 1900 La Plata, Buenos Aires, Argentina \\ ${ }^{2}$ CONICET, Argentina \\ ${ }^{3}$ Laboratorio de Botánica Sistemática y Etnobotánica, Facultad de Ciencias Agrarias, Universidad Nacional de Jujuy, \\ San Salvador de Jujuy, Argentina \\ ${ }^{4}$ Instituto de Biología Subtropical, CONICET, Facultad de Ciencias Forestales, Universidad Nacional de Misiones, CeIBA, \\ 3370 Puerto Iguazú, Misiones, Argentina
}

Correspondence should be addressed to María Lelia Pochettino; pochett@fcnym.unlp.edu.ar

Received 4 May 2013; Accepted 4 July 2013

Academic Editor: Ana H. Ladio

Copyright (C) 2013 Pablo C. Stampella et al. This is an open access article distributed under the Creative Commons Attribution License, which permits unrestricted use, distribution, and reproduction in any medium, provided the original work is properly cited.

\begin{abstract}
This contribution presents information about the history of introduction, establishment, and local appropriation of Eurasian fruit trees-species and varieties of the genera Prunus and Citrus - from 15th century in two rural areas of Northern Argentina. By means of an ethnobotanical and ethnohistorical approach, our study was aimed at analysing how this process influenced local medicine and the design of cultural landscape that they are still part of. As a first step, local diversity, knowledge, and management practices of these fruit tree species were surveyed. In a second moment, medicinal properties attributed to them were documented. A historical literature was consulted referring to different aspects on introduction of peaches and citric species into America and their uses in the past. The appropriation of these fruit-trees gave place to new applications and a particular status for introduced species that are seen as identitary and contribute to the definition of the communities and daily life landscapes. Besides, these plants, introduced in a relatively short period and with written record, allow the researcher to understand and to design landscape domestication, as a multidimensional result of physical, social, and symbolic environment.
\end{abstract}

\section{Introduction}

The native human groups-diverse in patterns of subsistence and settlement strategies-that, since prehispanic times, inhabit different ecological territories of our country, constructed particular cosmovisions. Those cosmovisions together with local knowledge shaped the practices of management and use of those plant resources that defined the local landscape while designing a dynamic physical space where the own meanings and values of each people were manifested themselves $[1,2]$. This process includes the features that define domestication (cultural selection and the emergence of a different reality), and its result is the construction of a cultural landscape that includes the dimension of biocultural phenomenon, in the sense that it is a physically, culturally, and historically determined environment $[1,3]$.

As of the process of European settling and peopling, like the Jesuit reductions and the founding of colonies in Argentine territory were, those cultural landscapes changed, as well as the characteristic ways of life of those ethnic group. So, the breakup of natives spaces occurred along with the establishment of a new regime of exploitation and production, either politically or culturally imposed by the Europeans, by means of the introduction of stuffs and products from the Old World, for instance, cattle and several 
crops that modified the configuration and representation of landscape [1,4-7].

The settling of Spanish colonies in America led to the beginning of plant species exchange between the New and the Old World that would affect multiple aspects of daily life in both continents. Studies seldom approach the changes produced since 1492 in the particular features of each group in agriculture, food, and even in their habits and customsas medicine, rituals, and religious celebration. Instead, there are many examples that refer to the expansion of plants since times much older than the arrival of Spaniards to America, and those cases show similar situations in other parts of the world, in particular the movements of goods and species from the East and the South (Africa) to the classical Mediterranean. Among them, "sugar cane" (Saccharum $\times$ officinarum L.) can be mentioned which was rapidly adopted in the South of Europe through the advance of Islamic Empire [8]. As well, the European contact with Africa in the middle 15th century was partially promoted for the desire of acquiring spices and condiments. The silk route, established by the 1st and 2 nd Century, constituted a very important commercial way for the exchange of cultivated spices. Plant species from the Old World arrived into America as part of culture and idiosyncrasy of Iberian people, for example, "wheat" (several species of Triticum), "barley" (Hordeum vulgare L.) and "rye" (Secale cereale (L.) M. Bieb.), "broad bean" (Vicia faba L.) and other pulses, seed and/or stone fruit trees of the gener Prunus, Cydonia, Malus, and Pyrus ("plum," "peach," "quince," "apple," and "pear"), and other temperate fruits, along with aromatic species and flowers that were included as exotic elements within American native communities [5, 9-11].

All kinds of vessels were constantly exchanging plant germplasm between both worlds, and besides seeds, fruits, and adult plants, the transportation of branches, shoots, and grafts was also frequent ("ramas, retoños, varetas y mugrones (ingertos) de algunos árboles ..." Anglería (1516) in de la Puente y Olea [12]), in barrels for wine. The main destination of these trips was Antilles and later the continent (which was named "tierra firme," that is, terra firma), Mexico and Peru the (16th Century). Then, according to chronicles, different access routes were followed. This route, known as CaribbeanAndean, was accompanied by the one of Asunción-La Plata River and the Brazilian one. Each of them had its own particularities related to interethnic relationships, the origin of the introduced germplasm, and the associated knowledge with each plant and its management (Figure 1).

1.1. Fruit Trees and Local Medicine. Many cultivated plant species with medicinal properties arrived to America, along with associated knowledge that was propagated by Spanish people. Their incorporation and appropriation by local people involved a process of assignment of properties, the progressive perception, and the search among the alternatives of obtaining, producing and applying of their medicinal use.

De la Puente y Olea [12] gave the first references of these medicinal species that were also mentioned in the description of the orchards of the priests of two Jesuit missions given

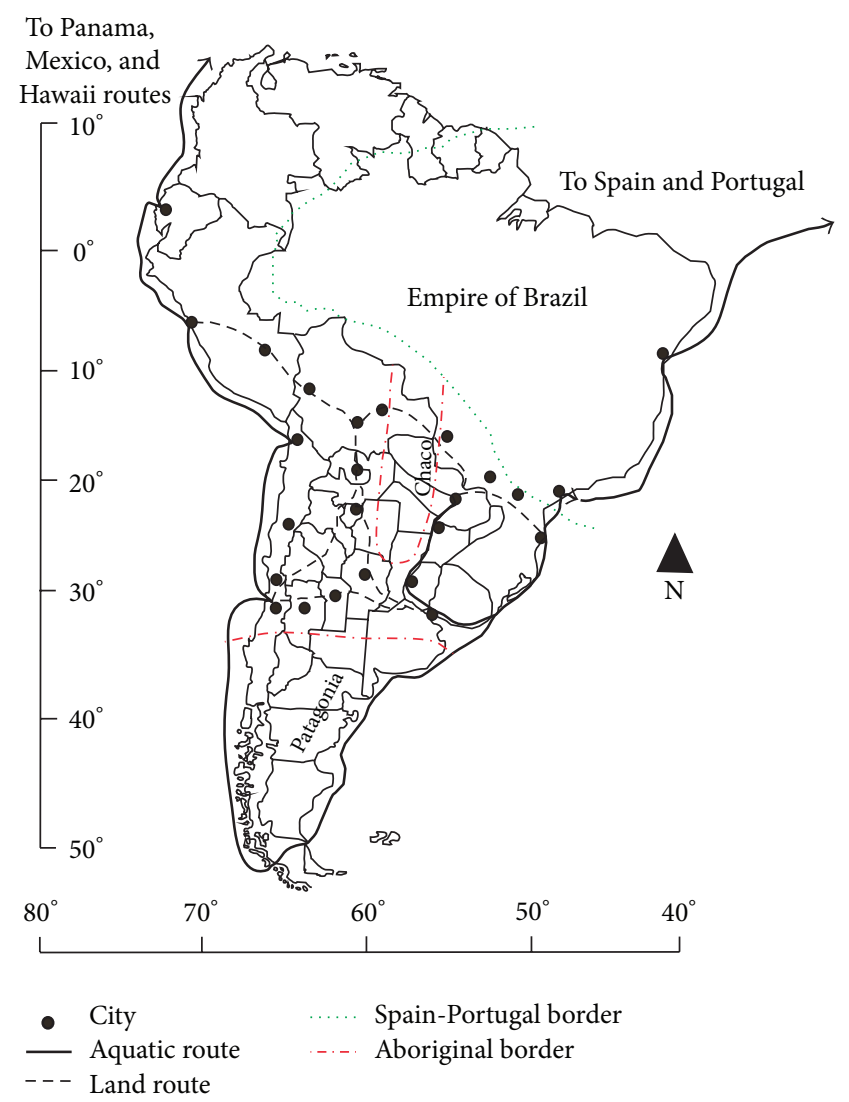

FIgURE 1: The Iberian conquest and colonization of America continent: an routes to terra firma of the 16th Century.

by Sepp [9] and Paucke [13]. Furthermore, several volumes about medicine and medicinal plants were found among Jesuits goods in the moment of their expulsion from America (Galeno de Pérgamo (the 2nd Century), Rivero, Johann Dolaeus (the 17th Century), and Suárez de Rivera, y Fuente Piérola (the 18th Century)), and it is supposed that they used also the books of Andrea Mattioli, Andrés de Laguna, Dioscórides and the Materia Medica of Father Joseph of Montenegro, and Father Segismund Asperger [14]. On the other hand, it is worth mentioning that all around the world, different human groups attribute medicinal value to their food, and in this way, the species considered in this contribution, which all have been originated in Asia or Eastern Europe, were added to the Mediterranean record of useful plants by their biodynamic properties as well: citric as insect repellent or antidote in poisoning and for diverse diseases and symptoms, while the fruit trees of rose family were valued as astringents, febrifuges, diuretics, and laxatives $[15,16]$. In the particular case of peaches, they were appreciated as a luxurious food, and in so much, they appear also in funebrial contexts in the Mediterranean [17]. These therapeutical uses, even if they do not remain unaltered through the time, reflect a minor incidence of commercial aspects than their use as food and also show the local appropriation of these plants through the generation of novel applications. 
Based on what is mentioned earlier, this contribution provides information about the medicinal use of two plant groups of Eurasian fruit trees in America, considering that their history of introduction, appropriation, and local recognition allows to interrelate them and to define them as representative elements of the landscape that they are currently part of. The two plant groups are part of larger scale studies and reflect the research performed by the authors on different periods and regions of Argentine subtropics: (a) the case of citric, Citrus L., from northeastern Argentina and (b) - "peaches," Prunus persica (L.) Batsch., from northwestern Argentina. From the ethnobotanical approach, the description, analysis, and comparison of the entry routes are presented, as well as the medicinal use of citric and fruit trees of rose family in the past and in the present. This kind of study allows to make a time projection with the historical data and ethnobotanical information to reach their appropriation significance.

\subsection{Description of Local Landscape}

1.2.1. Northeastern Argentina (NEA): Phytogeographic Districts of "Campos" and "Urunday" in the South of Misiones. Field works have been performed in two departments of the south of the province, San Ignacio (in the Paraná river bank) and Concepción de la Sierra (near the Uruguay river). This zone is a transition between the District of Campos and the District of Selvas Mixtas [18], where Martínez-Crovetto [19] places the district of Urunday. In this region, gallery forests form corridors along Parana and Uruguay River and also along the course of the main streams, and they also cover the slopes of low hills as Santa Ana, San Juan, or San José. This is an impoverished forest, in transition to savanna, where forest islands within a grass matrix can be observed, which is locally known as "capones" [20]. The populations settled there are expressive of the history of the region. Diverse ethnic groups inhabited the area before the European arrived there, and since the beginnings of the 20th Century, several migratory waves have arrived. At present, a mosaic of different cultures can be found in the area shaping mixed communities: the "Criollos," Mbya Guarani people and the descendents of Polish, Ukrainians, Italians, Spaniards, Brazilians, and Paraguayans, among others. The studied communities of Teyú Cuaré and Cerro Mártires are a good example of people diversity, and they can be defined as peasant communities [21]. This diversity is also reflected in the language as both Spanish and Guarani are spoken and also a local variation of Portuguese (in the Uruguay river area). As for the economy, local groups derived their subsistence from the "monte" (local name for the forest, [3]) through hunting, fishing, and gathering, and they also practiced a swidden horticulture of Manihot esculenta Crantz, Ipomoea batatas (L.) Lam., Zea mays L., and different species of Phaseolus and Cucurbita, along with other crops of low lands [22-25]. Native people living in the zone still carry out these activities, and they have added cultures introduced in the area by the Europeans, for instance, Oryza sativa L. and recently Glycine $\max ($ L.) Merr. They have also introduced livestock raising (cows, sheep, and minor animals). At present, the most important economic activities in Misiones are silviculture and agriculture, complemented with cattle raising. The first of them is based on monoculture of "pine" (Pinus spp.) and "eucalyptus" (Eucalyptus spp.) destined to paper and wood industries settled in the area, which are in turn job source for many inhabitants. The principal crops are "tobacco" (Nicotiana tabacum L.), "yerba mate" (Ilex paraguariensis A. St.-Hil.), "tea" (Thea sinensis L.), and fruit trees, mainly citric (C. reticulata, C. $\times$ aurantium, and $C . \times$ latifolia). In summary, the economy of the province is based in extractivism or production of raw material with low industrial development $[26,27]$. In accordance with this scope, all the families interviewed in rural contexts are characterized by their traditional systems of subsistence production, with the occasional sale of surplus in urban tax-free fairs.

1.2.2. Northwestern Argentina (NWA): Dry Valleys and Yungas (Cloud Forests). Field works have been carried out in peasant communities of northwestern Argentina, settled in both western and eastern slopes of Andean foothills. In the west, the research was conducted in intermountain valleys in the localities of Juella and Yacoraite, in Humahuaca Ravine (province of Jujuy), and in the East in two areas in the province of Salta, in Los Toldos valley (Santa Victoria Department) as well as in the villages that are settled in the old Farm San Andrés (in Orán department) (Figure 2).

Western intermountain valleys correspond, from the phytogeographic point of view, to the Prepuneña or BolivianTucuman province, characterized by a xerophytic vegetation, while the eastern slopes belong to Yungas or cloud forest, which are determined by the presence of orographic rainfall that define an exuberant vegetation, which varies according to the elevation shaping three different environments: Pedemontane Forest, Montana Forest, and Montane Cloud Forest $[18,28]$. In spite of the marked differences resulting from the features of vegetation and general environment, in both regions agriculture is performed, destined not only to family consumption but also to the sale of products in fairs and regional markets. This subsistence strategy has a long history in the zone, where in addition to the typical American triada (Z. mays_-Phaseolus spp.-Cucurbita spp.), several crops characteristic of Southern Andean Area were grown, for example, Chenopodium quinoa Willd., Solanum tuberosum L., and other species of Andean tubers like Oxalis tuberosa Molina and Ullucus tuberosus Caldas, among others [29-31].

The inhabitants of these locations are descendents of native people; most of them with different degrees of miscegenation with Europeans arrived to the zone in different moments. The language there spoken is a local variant of Spanish, with the persistence of some words and grammatical structures of Kechwa and Aymara [32-35].

\section{Materials and Methods}

The present study is the result of a major ethnobotanical research conducted in different stages. In the first moment, 


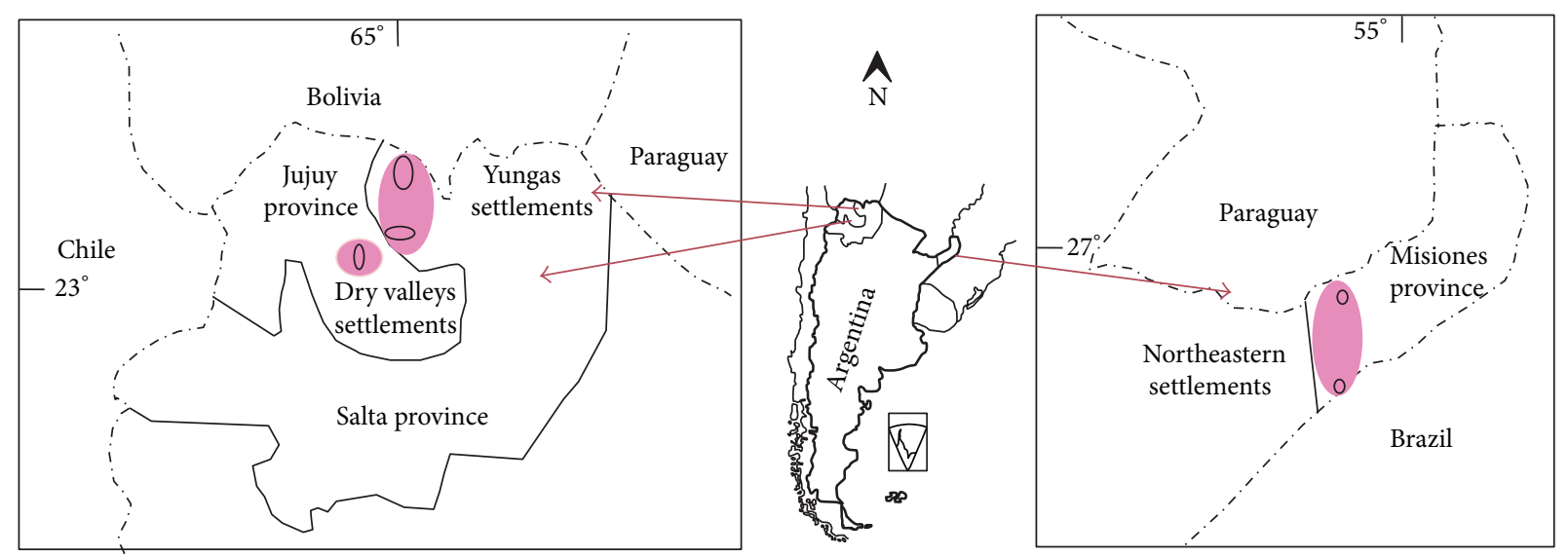

FIGURE 2: Localization of study areas in northwestern and northeastern Argentina.

the issue of agrobiodiversity richness and ways of management were approached, and then the aspects related to local uses of the fruit trees were studied in depth to obtain generalizations, in particular the therapeutic applications that are the basis of this contribution. In Yungas, field work was performed between the years 1994 and 2000, with the purpose to enquire about traditional medicine and phytotherapy in general. In dry valleys and northeastern Argentina, the researches started in 2010 and still continue. In both cases, the object of the study is the local knowledge and management of species and varieties of the genera Prunus and Citrus, respectively. Qualitative techniques have been used. The first settlers that took part in the research were randomly selected, and in some cases, the strategy of snow ball was applied $[36,37]$. In NWA, the number of participants in the research reached in Yungas 59 people, in dry valleys 20 people, and in NEA 36 people. The interviews were oriented to the enquiry about local knowledge on the name or names by which the species are recognized, useful parts and allotted uses, with special reference to the therapeutical ones, including way of preparation and administration. Likewise, by means of the review of a total of 38 bibliographic sources and historic documents of different nature, ranging from the beginning of the 16th century to the present, the search for medicinal uses has been widened, and information about the entry of these crops in America was obtained. The uses of these ethnovarieties in the past and in the present were compared by means of chi-square test. Voucher and other support materials (like branches and leaves, as well as fruits) have been collected in the field in the company of local inhabitants. This plant material has been botanically identified [38-43], its taxonomy was controlled and updated $[44,45]$, and then it was deposited in the Herbary of Useful Plants and Collection of Fruits and Seeds (CFS) of the Laboratorio de Etnobotánica y Botánica Aplicada (LEBA) of the Facultad de Ciencias Naturales y Museo, Universidad Nacional de La Plata, and in the Herbary of Museo de La Plata (LP). They have been assigned the initial and number of personal records of each collector.

\section{Results and Discussion}

3.1. History of Entry Arrival and Use of Citrus in NEA. Citrus is native of east, south, and southeast of Asia, Australia, and southwest of Pacific Islands [44]. Most of citric species were introduced in Europe by Muslims during the 10th and 11th [46] with the only exception of "citron" (Citrus medica L.) that was already known by Greeks and Romans, and those fruits that were later introduced like "sweet orange" (Citrus $\times$ aurantium L.), "tangerine" (Citrus reticulata Blanco), and "grapefruit" (C. $\times$ aurantium). Citric were brought to America during the second trip of Columbus in 1493. The chroniclers of that period mentioned that seeds of "oranges," "lemons," and "citron", as well as "melons" and all sort of vegetables (pepitas y simientes de naranjas, limones y cidras, (además de) melones $y$ de toda hortaliza [47]), have been taken to Central America from the Gomera Island (that belongs to the Canarias archipelago). These references would correspond to C. $\times$ aurantium L., C. $\times$ limon (L.) Osbeck, C. medica, and Cucumis melo L., respectively. To these "species" (in strict sense, hybrid taxa or cultivated varieties [44]), de la Puente y Olea [12] added "toronjas" that would belong to C. maxima (Burm.) Merr., "limas" of the group of C. $\times$ aurantifolia (Christm.) Swingle, and C. $\times$ limettioides Tanaka. These authors also pointed out that the first routes of introduction of cultivated plants had been Andalucía and Castilla, in Spain; Guinea in Africa; and in Asia "orange" trees with large fruits which had been introduced from Filipinas. By the last quarter of the 16th century, several representatives of genus Citrus, as "oranges" and "lemons," were already naturalized in the Americas. Father Joseph de Acosta (who arrived to Peru in 1572) mentioned that citric were the trees that had more and better developed, and he was surprised because of the presence of orange groves, as well as other citric including "limes," "citron," and similar ("limas, cidra, and y fruta de este linage" [48]). Those cultivars of Citrus that had been managed or domesticated in lesser extent, particularly those used as rootstocks for grafted plants, show a special easiness to naturalization, related to the environments where they have been planted, local people, fauna that eats their fruits, 


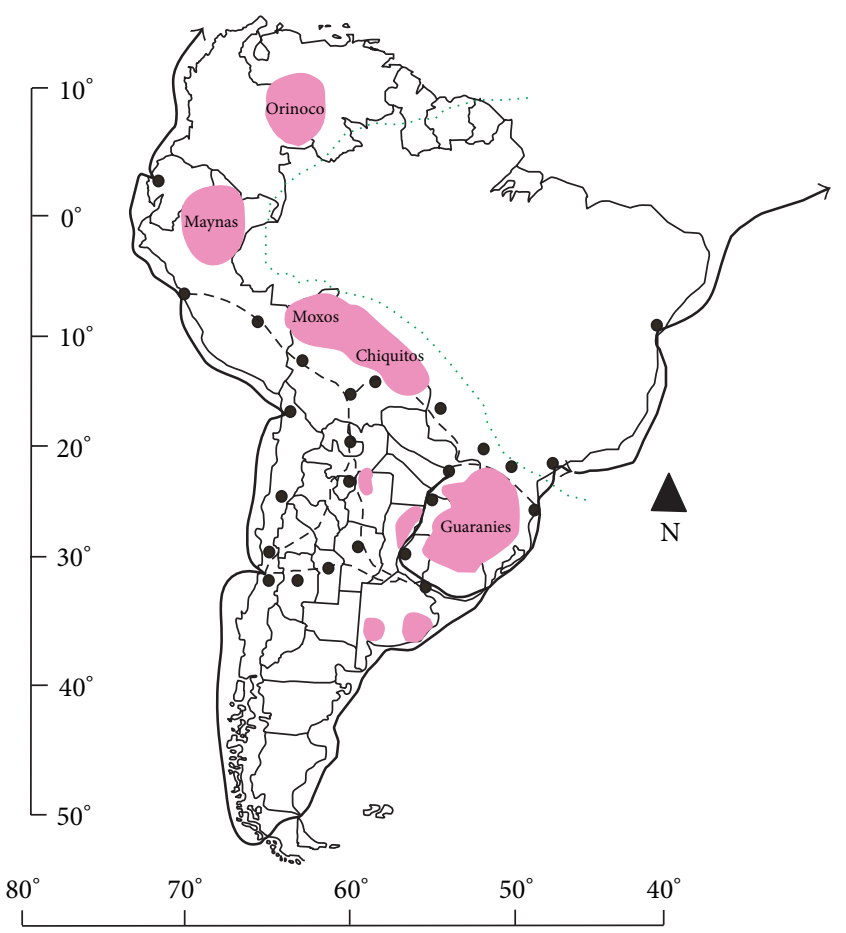

$$
\begin{aligned}
& \begin{array}{lll}
-\quad \text { City } & \ldots . . & \text { Spain-Portugal border } \\
- & \text { Aquatic route } \quad & \text { Jesuit missions }
\end{array} \\
& \text { - - - Land route }
\end{aligned}
$$

Figure 3: The result of the Iberian conquest and colonization of America continent: Latin American Jesuit Missions (the 17th and 16th Centuries).

and their own process of hybridization and apogamy that are complementary of sexual reproduction [1]. It seems that the entry (as well as the exit) of plant germplasm was continuous and copious and more diversity appeared at the same time when the different areas of the world met in touch.

During the Jesuitical period, citric were cultivated in different plots within the Guarani missions (Figure 3). The major diversity of fruits was found in the gardens of the priests and in the colleges [1]. In addition, there were "orange" groves belonging to the Tupambae (that were those community gardens for the production in large scale) destined not only for local consumption but also for the sale $[49,50]$. The fruits were used in medicinal preparations against putrid fever (typhus), intestinal parasites, and stomach diseases, as appetizers and as antidotes against snake bites and other poisonous animals. The juice of the acidic varieties was considered to have cold properties in the frame of humoral medicine, and they were also uses as excipients and sweeteners, for instance, the syrup and bark of "citron" or "lemons" $(C . \times$ limon $)$. Orange wine is cited as the most healthy of all liquors, and it is used as other spirits distilled from fruits, as a remedy for coldness in native people. This wine was made with orange juice fermented in big glass bottles with sugar, added with wine yeast fifteen days later and left to stand for a whole year [51].
"Orange" flower water was used (and it still is) in confectionery and the "bergamota" water $($ C. $\times$ limon $)$ in perfumery $[9,52,53]$. After the Jesuits expulsion (1767), other uses are mentioned as, for instance, the use of bitter "orange" peel ( $C$. $\times$ aurantium) to calm the ache of dysentery and as a tonic too; the juice of "lima suti" (C. $\times$ aurantifolia) to stop paludic fever ("chucho") and against the rush called "sudamina" o "zarpullido". Nevertheless, some of these properties have been already discussed by Piso in the 16th century [54].

As from the contribution of Paucke [13] in the inventories of the Jesuits expulsion made by Brabo [55], a record of the cultivars grown in Jesuitical missions can be approached. There were cultivated "lemons," "sweet lemons," "limones ceutíes," "sweet limes," "citrons," "toronjas," and "sweet and sour oranges", including cultivars like "Chinese orange" and others "oranges with fine peel." Selected varieties were often cultivated in orchards and gardens of Jesuits, where only the priests and a few chosen Guarani people, particularly skilled for horticulture, were allowed to enter. They were also grown in the colleges of the order placed in Buenos Aires, Córdoba, Santa Fe, and Asunción del Paraguay. The cultivars considered that commons or vulgar were frequently cultivated in the Tupambae and occasionally in several Abambaeplots assigned to each family for subsistence production. Additionally, those varieties locally considered as "wild" grew spontaneously, in process of naturalization, in different spaces more or less modified by agroforestal management.

With the estrangement of the religious order from Spanish colonies in 1768, missions were abandoned and during the following year, multiple migrations occurred to the neighbouring forest, to Corrientes, Santa Fe, Buenos Aires, and Asunción, among other places [50]. Gardens were abandoned and a process of forest regeneration took place in several patches, formerly cultivated. It had to be expected that these anthropogenic landscapes were managed, especially those closer to buildings - some of them inhabited for a short period, despite the Portuguese and Paraguayan invasions in 1817 and 1818, in particular, fruits, yerba mate, and cotton (Gossypium sp.) groves, no longer functional. Orange groves still remain by the interviewed settlers as present a few years ago, and they have been described and praised by the travelers in Misiones during the end of the 19th Century and the beginnings of the 20th [56-60].

\subsection{History of Arrival and Use of "Peaches" in NWA. Prunus} persica (Prunoideae) is a species belonging to the botanical family Rosaceae. The genus is subdivided into several subgenera according to the morphology of the fruit. Based on bibliographic record, its origin can be established in the mountainous zones of Tibet and southwest of China. Peaches could be found in the Mediterranean by the principles of Christian area; nevertheless their taxonomy and history of evolution under domestication are still not completely elucidated as for origin and dispersal centers [61, 62].

The first galleons and other vessels coming from Sevilla arrived at the Antilles early in the 16th Century. They brought among other fruits (as mentioned previously) the fruits from the Castillas or stone fruits among which a special reference 
to "peaches" is made. Later, this germplasm entered Mexico and Peru (mainly in Lima), and from these points, the crop was expanded to the rest of the continent [12].

In the specific case of the populations of NWA, historical sources and records show that these exotic fruit trees were introduced from Chile-following the route of the Pacificby the decade of 1550 by the expedition of Nuñez de Prado. They thrived and by December 1552 a wealthy fructification was described ("ya surgían exuberantes los frutos de las primeras siembras de los españoles" [63]).

The first seeds possibly arrived to Santiago del Estero, which was equidistant in the route of communication between Peru and the Atlantic Ocean and from there distributed to other provinces that were part of the colonial government of Tucuman, created in 1563 and constituted by the present Argentine provinces of Jujuy, Salta, Tucumán, Catamarca, Santiago del Estero, and the center of Córdoba. During this period, the influence of Chile on this government stopped and the district remained under the authority of Peru viceroy. The political space of Tucumán was born as a consequence of the discovery of Río de la Plata Litoral and the exploration of the route that connect it with Peru. Its occupation was guided by the need to expand the territory and to find new lands suitable for cultivation. Unlike the native groups that inhabited the south of Argentine territory, the Andean partialities that were comprised in this government have been soon subjected to the new administration after the arrival of the Spanish founders. Such was the case that by the second half of the 16th and beginning of the 17th Century, native people managed European crops, although these plants did not integrate their daily diet $[4,5,63-65]$.

By that moment, in Argentina, the subsistence economy was based on the exploitation of native workforce to labor in the country with plants and animals introduced from Europe, with some local exceptions like "maize." In 1590, a process of internalization of commercial circuit occurred, which became an integrated market from Potosi to Buenos Aires passing through Tucumán. Thus, the influence of Chile on NWA region was relegated [66]. In this frame, Jujuy was considered during colonial period a pathway employed by natives and Spaniards to arrive to Peru, and it constituted a border of Tawantinsuyu (Inca Empire) and later a pathway to Bolivia (Potosí) [67].

Along with the food use of peaches, there are archaeological evidence of their ceremonial use in ritual contexts by native people during Spanish-Indigenous period by the year 1600 [68]. Regarding their medicinal applications in the zone, the earliest mentions date from colonial period and referred to the use of peaches as natural laxatives. In fact, in different publications referring to European uses of "peaches," the flowers and leaves are mentioned as to be used in infusion and/or syrup as child laxatives. Nevertheless, it is warned that flowers could be toxic because of the presence of amygdaline, more abundant in some varieties than in others $[43,69,70]$. Poultices with the leaves on the abdomen are recommended against parasites, as anti-inflammatory, and to heal wounds and herpes. The infusion of leaves with milk is also mentioned as antiparasitic. The distilled water of flowers is used to remove specks from the skin. Dry and powdered leaves are used to heal grains and furuncles and mashed seeds with egg white to stop hemorrhages [71].

3.3. The Current Situation of Citrus. By the end of the 19th Century, Burmeister [71] referred to the presence of "naranjos mandarinos" (tangerines, C. reticulata) in the province of Corrientes, and he recommended their intensive cultivation together with "common oranges" and "chirimoyo" (Annona cherimola Mill.) to export the fruits to large cities. A few years early, Hieronymus [72] included them in his publication about medicinal plants of Argentina under the name of "naranjo fino" o "mandarino" (before Citrus deliciosa Tenore, now $C$. reticulata) with the same uses than "sweet orange" (against scurvy, antitussive, and against bile diseases). "Pomelos" or "grapefruit" (C. $\times$ aurantium) entered possibly by the same time or shortly before than "tangerine." It is still discussed if "grapefruit" is a result of mutation or hybridization, but there is agreement to consider Barbados as the place of geographic origin by the principles of the 18th Century, from where it disperses to the other Antilles islands not before a Century later [73, 74]. Maybe "grapefruits" were mistaken for "pampelmuse" or "toronjas" (C. maxima). These new introductions were coincident with the reconfiguration of local people through the migratory process that had place in the first years of the 20th Century. The first immigrants were brought to Misiones by official colonization that started in 1898 with the arrival of Polish and Ukrainians from Galitzia (one of the poorest zones of rural Europe) to the village of Apóstoles. The state was also responsible for the peopling of those lands of dorsal central ridge (Além, Oberá, and Cainguás). On the other hand, private colonization incorporated mainly Deutsch immigrants from Brazil or directly from Europe, and it covers mainly the zone of Upper Paraná. Later, Creole and Paraguayan immigrants arrived looking for job [75].

New wisdoms and practices on the environment arrived with the immigrants, as well as a different valoration of the plants with which they interacted; for example, the "oranges," that in the new land were very common, in the origin countries were such a precious good that they were given as a present for Christmas. Another source of variability appeared with the industrialization of citric cultures. After the first quarter of the 20th Century, coincident with the start of citriculture in NEA, diverse cultivars were introduced from different parts of the world (Africa, India, USA, China, and Japan). The model of citric industry is the one developed in the states of Florida and California (USA) that consisted of new varieties grafted on rootstocks of "sour orange," which was later replaced-because of CTV (Citrus tristeza virus, a kind of Closterovirus) epidemy-by rootstocks of "sweet orange," "Cleopatra orange," "Rangpur lime," and "sweet lime", among others [76-79]. By the decade of 1970, a homogenization took place because of the increasing agrarian globalization and market request for uniform fruits as for size, shape, colour, and taste. At present, $78 \%$ of cultivated citric belong to "tangerines" ("Satsuma," "Clementina," and "Murcott"), 17\% to "oranges" ("Valencia Late," "Salustiana," "Lanelate," and "Newhall"), and the remaining $5 \%$ to 
TABLE 1: The citric of NEA: local varieties and their botanical identity. The $*$ indicates the presumable local ethnovarieties.

\begin{tabular}{|c|c|c|c|}
\hline Local name & Local variety & Botanical species & Voucher \\
\hline Cidra & Cidra & Citrus maxima (Burm.) Merr. & Stampella 34 (LP) \\
\hline \multirow{3}{*}{ Pomelo } & Pomelo cidra & C. maxima $\times$ Citrus $\times$ aurantium $\mathrm{L}$. & Not collected \\
\hline & Pomelo blanco* $^{*}$ & C. $\times$ aurantium (grupo pomelo) & Stampella 19 (LP) \\
\hline & Pomelo rosado & C. $\times$ aurantium (grupo pomelo) & Stampella 78 (CFS) \\
\hline \multirow{3}{*}{ Apepú } & Apepú silvestre* & $\begin{array}{l}\text { C. } \times \text { aurantium (grupo naranja } \\
\text { amarga) }\end{array}$ & Stampella and Hilgert 10 (LP) \\
\hline & Apepú casera* ${ }^{*}$ & $\begin{array}{l}\text { C. } \times \text { aurantium (grupo naranja } \\
\text { amarga) }\end{array}$ & Stampella 85 (CFS) \\
\hline & Apepú dulce* & $\begin{array}{l}\text { C. } \times \text { aurantium (grupo naranja } \\
\text { amarga) }\end{array}$ & Stampella 53 (CFS) \\
\hline \multirow{7}{*}{ Naranja } & Naranja silvestre $^{*}$ & C. $\times$ aurantium (grupo naranja dulce) & Stampella $128(\mathrm{LP})$ \\
\hline & $\begin{array}{l}\text { Naranja silvestre de fruto } \\
\text { grande }\end{array}$ & C. $\times$ aurantium (grupo naranja dulce) & Stampella 162 (CFS) \\
\hline & Naranja casera* & C. $\times$ aurantium (grupo naranja dulce) & Stampella 112 (CFS) \\
\hline & Naranja injertada & C. $\times$ aurantium + Citrus trifoliata $\mathrm{L}$. & Commercial cultivar \\
\hline & $\begin{array}{l}\text { Naranja de ombligo } \\
\text { (injertada) }\end{array}$ & $\begin{array}{l}\text { C. } \times \text { aurantium "Ombligo" }+ \\
\text { C. } \text { trifoliata }\end{array}$ & Commercial cultivar \\
\hline & Naranja calderón & C. $\times$ aurantium "Calderón" & Commercial cultivar \\
\hline & Naranja que guía & C. $\times$ aurantium & Not collected \\
\hline \multirow{8}{*}{ Mandarina } & Mandarina silvestre $^{*}$ & $\begin{array}{l}\text { Citrus reticulata Blanco "Común de } \\
\text { Concordia" }\end{array}$ & Stampella 103 (LP) \\
\hline & Mandarina casera ${ }^{*}$ & C. reticulata "Común de Concordia" & Stampella 121 (CFS) \\
\hline & $\begin{array}{l}\text { Mandarina injertada (con } \\
\text { lima) }\end{array}$ & $\begin{array}{l}\text { Citrus reticulata "Okitsu" }(=C \text {. } \\
\text { unshiu })+ \text { Citrus } \times \text { limettioides Tanaka }\end{array}$ & Commercial cultivar \\
\hline & $\begin{array}{l}\text { Mandarina injertada (con } \\
\text { limón cidra) }\end{array}$ & $\begin{array}{l}\text { Citrus reticulata "Encore" }+ \text { Citrus } \times \\
\text { limon (L.) Osbeck (=C. jambhiri } \\
\text { Lush.) }\end{array}$ & Stampella $116(\mathrm{LP})$ \\
\hline & Mandarina injerto con apepú & C. reticulata "Encore" & Stampella, Cabanillas, and Hilgert 172 (CFS) \\
\hline & $\begin{array}{l}\text { Mandarina colorada o } \\
\text { mandarinola }\end{array}$ & $\begin{array}{l}\text { C. reticulata "Cleopatra" (=C. reshni } \\
\text { Tanaka) }\end{array}$ & Stampella, Cabanillas, and Hilgert 170 (CFS) \\
\hline & Mandarina colorada japonesa & C. reticulata "Okitsu" & Stampella, Cabanillas, and Hilgert 175 (CFS) \\
\hline & Mandarina bergamota & C. reticulata "Encore" & Stampella $86(\mathrm{CFS})$ \\
\hline \multirow{6}{*}{ Limón } & Limón o limón común* & C. $\times$ taitensis Risso (=C. limonia Osb.) & Stampella $80(\mathrm{LP})$ \\
\hline & Limón amarillo & Citrus $\times$ limon"Verna" (=C. limon $)$ & Commercial cultivar \\
\hline & Limón lima & Citrus $\times$ latifolia Tanaka & Stampella, Keller, Núñez, and Dutra 60 (CFS) \\
\hline & Limón cidra o limón rugoso & $\begin{array}{l}\text { Citrus } \times \text { limon }(\text { L. }) \text { Osbeck }(=C . \\
\text { jambhiri) }\end{array}$ & Stampella, Hilgert, and Furlan 132 (CFS) \\
\hline & Limón sutíl o lima ácida & $\begin{array}{l}\text { Citrus } \times \text { aurantifolia }(\text { Christm.) } \\
\text { Swingle }\end{array}$ & Not collected \\
\hline & Limón real o limón aromático & $\begin{array}{l}\text { Citrus } \times \text { limon }(\text { L. }) \text { Osbeck }(C . \times \\
\text { latifolia } \times \text { C. maxima? })\end{array}$ & Stampella, Cabanillas, and Hilgert 177 (CFS) \\
\hline Lima & Lima, lima dulce & Citrus $\times$ limettioides Tanaka & Stampella 79 (CFS) \\
\hline Quinoto & Quinoto & $\begin{array}{l}\text { Citrus japonica Thunb. (=Fortunella } \\
\text { japonica [Thunb.] Swingle) }\end{array}$ & Stampella, Hilgert, and Furlan 150 (CFS) \\
\hline Trifoliata & Trifoliata & $\begin{array}{l}\text { Citrus trifoliata L. (=Poncirus } \\
\text { trifoliata } \text { Raf.) }\end{array}$ & Not collected \\
\hline
\end{tabular}

"lemons" (“Tahiti” and "Eureka") [80]. In spite of this, several cultivars - some of them in a naturalized status [81, 82] - are conceived by most of the interviewed people as native fruit trees. "Apepú," "naranja común," "mandarina común," "lima dulce," and "limón mandarina" are considered wild fruits (from the "monte"). All the informants agree in considering "apepu" as native and wild, belief strengthened by the fact that this plant has a Guarani name. "Apepu" has different interpretations: some authors consider it formed by the prefix $a$ meaning fruit, $p e$ that is peel, and $p u$ meaning noise 
TABLE 2: Ethnovarieties (locally recognized varieties) of peaches (Prunus persica) from dry valleys in NOA.

\begin{tabular}{lcr}
\hline $\begin{array}{l}\text { Group of ethnovarieties of durazno } \\
\text { (Prunus persica) }\end{array}$ & Ethnovariety & Voucher \\
\hline & Amarillo entero & 31 Lambaré (CFS) \\
& Amarillo corazón rojo & (CFS) \\
$\begin{array}{l}\text { Durazno común (endocarp adhered to } \\
\text { mesocarp) }\end{array}$ & Blanco & Rambaré (CFS) \\
& Dosado & 45 Lambaré (CFS) \\
& Durazno jorge (=Cholo Cholito) & Lambaré (CFS) \\
Durazno prisco (=Frisco that can be & Amarillo & 60 Lambaré (CFS) \\
opened) (endocarp not adhered to & Blanco & 46 Lambaré (CFS) \\
mesocarp) & Rosado & 50 Lambaré (CFS) \\
\hline
\end{tabular}

and breakup [83]. Others [84] instead consider that "apepu" means flaccid, but ape would be dorsum or surface and $p u$, hollow sound, in reference to the noise made by the epicarp when knocked with the fingers, a distinctive feature of this fruit.

As a result of this research, 8 ethnospecies of Citrus (including 27 ethnovarieties) have been recorded which are summarized in Table 1. Local ethnovarieties are those generally named as "communes," "caseras," and "silvestres" (that mean common, domestic, and wild, resp.) and are marked in Table 1 . They are coincident with those historically cultivated by the "Criollos" and can be found in the monte and also in old houses made of perishable material, known as "tapera" (that means abandoned house).

3.4. The Current Situation of "Peaches". Early introductions of seed and stone fruit trees of the rose family resulted in the establishment of local cultures, which have been maintained by means of both seed or vegetative reproduction, but without the introduction of new germplasm. For that reason, those fruit trees populations are constituted by the same varieties introduced in times of the Colony, but they reflect local criteria of cultural selection as well as plant adaptations to a particular environment. In the case of "peaches," those 500 years of history in the new settlement shaped a complex of 9 ethnovarieties comprised within 2 groups of ethnovarieties (Table 2) locally identified by diverse attributes that diverge from those prized by the market [85]. In this way, and although in the last years commercial "peaches" cultures were intended, in contrast to what happens with the citric in NEA, here the industrial cultivation of "peaches" has not been established, and the commercial varieties introduced did not represent an instance of diversification or entry of novel germplasm to local crop. The permanence is observed too in food and therapeutical uses given to these plants. Many inhabitants of dry valleys make a preserve ("compota") with dry "peaches" ("pelones") boiled with sugar, and the juice of the preparation is used to treat kidney diseases [86]. In Yungas, settlers cultivate "peaches" in the middle stage of the forest. There, a decoction made of dry flowers and powdered seeds is made to treat diseases related to intestines (diarrhea, flatulence, and intestine inflammation). The preparation is drunk three times a day, and if discomfort still persists, it can be taken for two consecutive days. The shoots are used in humoral medicine and soaked in vinegar, in frictions to remove heat from the body, or in infusion that has to be drunk three times to stop "chucho" (very high fever with sweat) [87]. The pulp of the fruit with apple pulp is mixed and mashed to use as a thickener element in the preparation of "yista": a solid mixture of plant components with basic properties used to chew "coca" (Erythroxylum coca Lam.) [88, 89].

The information referred to the use of the previously mentioned ethnovarieties in the past, according to the literature, as well as the recorded uses in the study area at present, is detailed in Table 3 and compared in Figure 4. By comparing the number of ethnovarieties used for each body system either in the past and in the present, higly significative differences ( $\chi 210$ g.l., $P<0.005=41.57$ ) appeared (Figure 5). In Figure 5, it can be observed that the uses for affections of digestive system are the most frequent in both periods and that nowadays the usage of these resources becomes more important in the treatment of diseases of respiratory system as well as the circulatory, osteo-artro-muscle ones and humoral medicine.

\section{Final Considerations}

Characteristics of native people and of colonization streams shaped cultural landscapes with particular traits that reflect on the identified plant species and their uses. Among the fruit trees introduced in the northern Argentina, peaches had a long history of use in Europe (although their centre of origin was Asia). When peaches were brought to the American continent, during the early conquest and colonization, they were introduced as luxurious foods, reproducing their history in Europe, where they had a reduced number of therapeutic applications. The citric, instead, by that time had a short history shared with European people, and they were much valued not only as food but as medicines too. In NWA, the colonizers introduced cultivated plants from Spain and entered from Peru or Chile, though some contacts with the introductions performed through Buenos Aires port (over Río de la Plata) could be mentioned. From the ecological point of view, Humahuaca Ravine and other dry valleys 


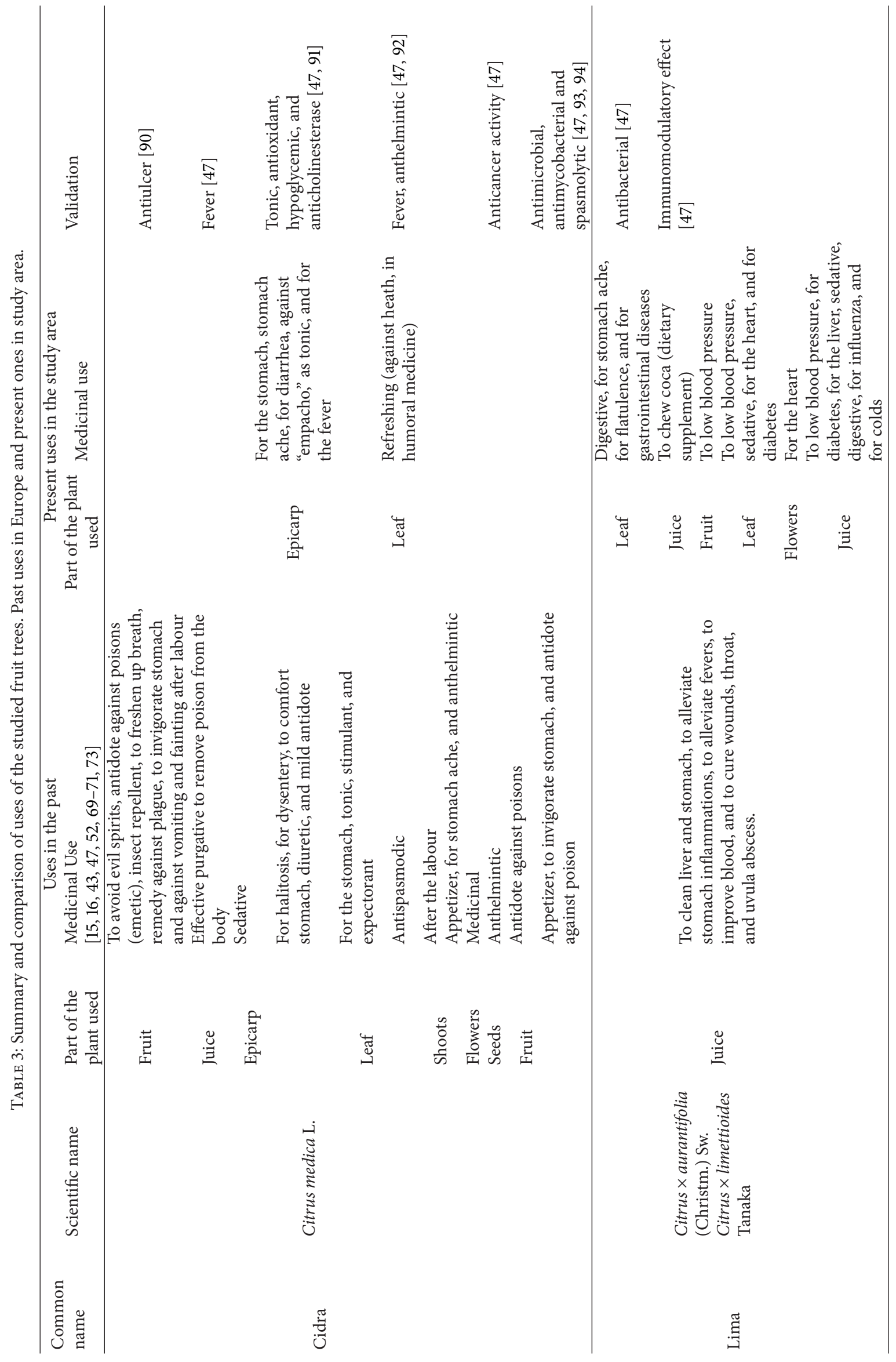




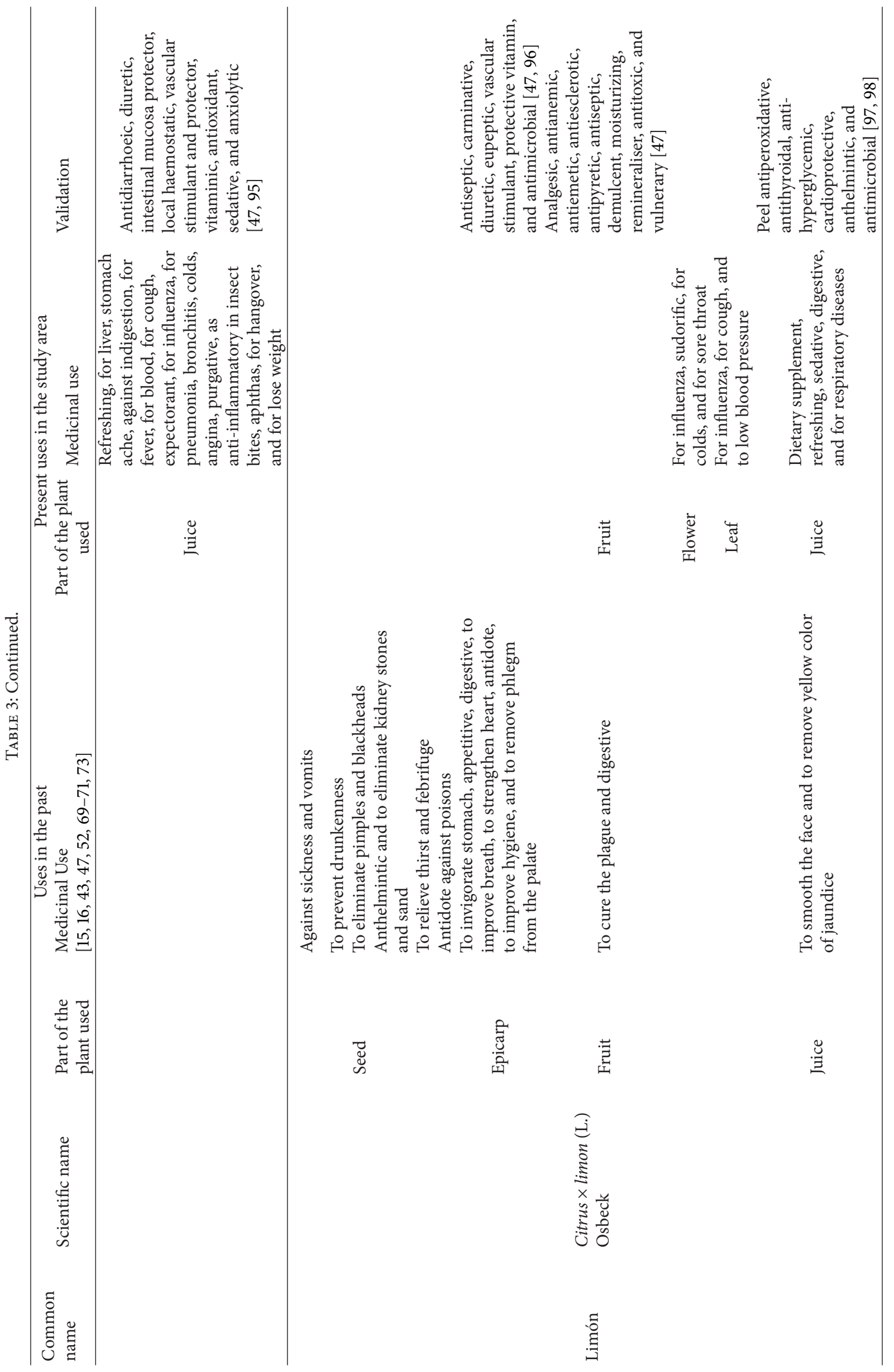




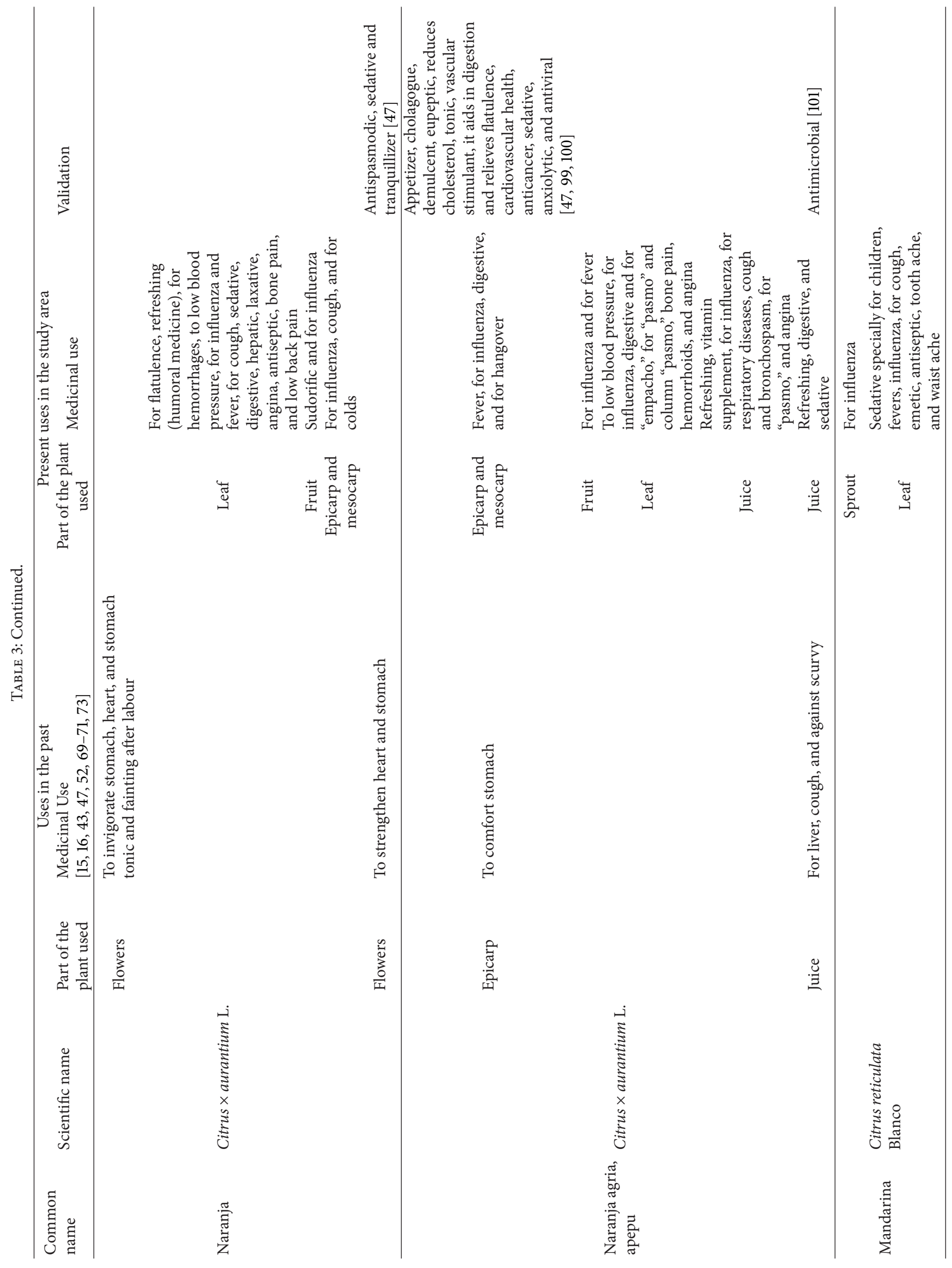




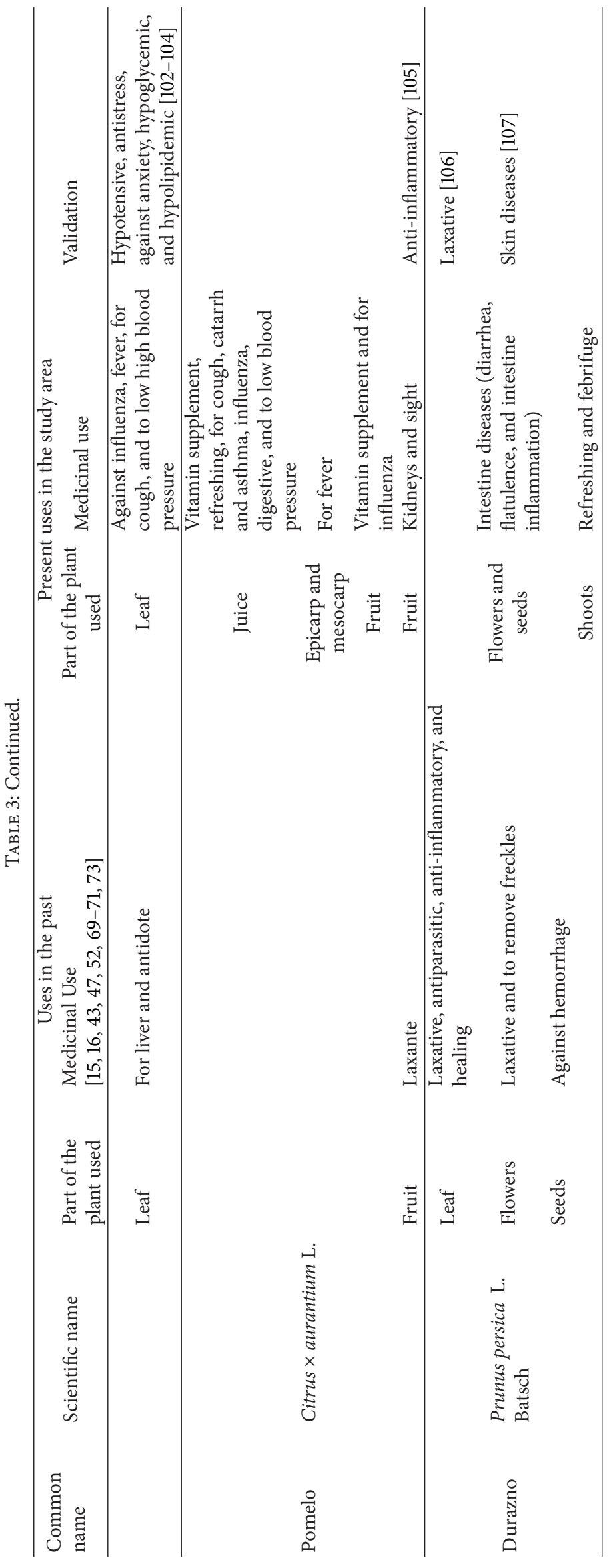




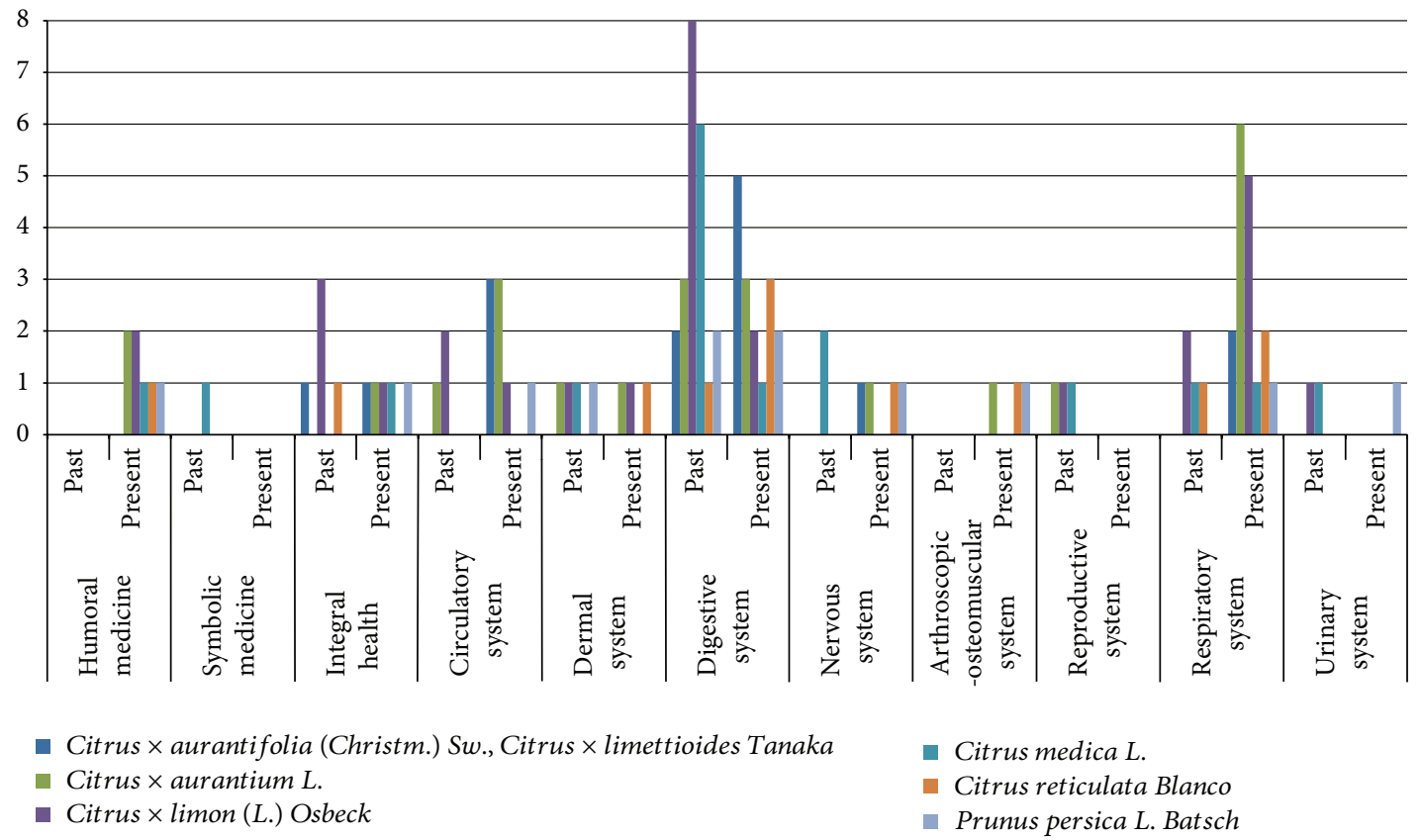

FIGURE 4: Number of therapeutic properties assigned per species per system.

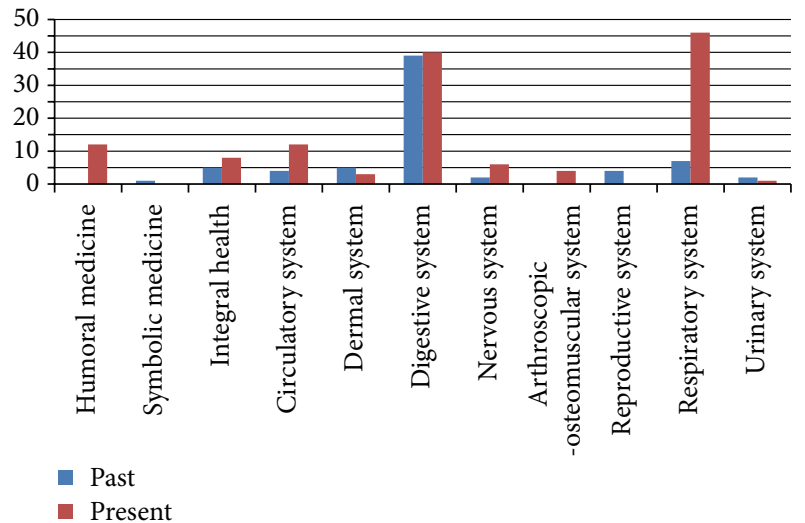

FIGURE 5: Number of ethnovarieties used for each body system in the past and present.

were good recipients of "peaches," "apples" (Malus domestica Borkh.), "pears" (Pyrus communis L.), and "quinces" (Cydonia oblonga Mill.). Consequently, both for cultural and environmental reasons, the local agricultural communities adopted rapidly these plants to cultivate them. But, along this process, new varieties consistent with local values had been selected, as well as those that showed more tolerance for the conditions in the new space. Thereby, varieties have been configured which are considered as defining a particular agricultural context and recognized as an identity factor by the settlers: "duraznos de la Quebrada" (in reference to Humahuaca Ravine). In NEA, on the other hand, the introduction of citric was the result of the confluence of two colonization streams: the Spanish one known as Río de la Plata-Asunción and the Brazilian one that summarized good apportations from
Portugal, Africa, India, and the southeastern of Asia. Such citric, through the agency of Jesuits, became conspicuous elements in local landscape and turned into characteristic cultures of the zone. Furthermore, several taxa have passed to a naturalized status, and now they characterize also the spontaneous flora and are considered by the inhabitants as native from the zone.

In both areas, NWA and NEA, in parallel to the establishment of these crops as an agricultural and economic resource, diverse use has been developed, for example, the therapeutic applications referred to throughout the text, and many of them are novel with respect to those uses recorded in other parts of the world, as a result of local experimentation. Either past or present uses, although diverse, seem to be founded on the antioxidant properties of the fruits here considered, taking into account that oxidative damage, caused by the action of free radicals, may initiate and promote the progression of a number of diseases such as the ones treated with citric and peaches.

Despite the differences, the examples here posed allow to understand the processes of local appropriation of introduced plants. The decision to incorporate foreign elements has to be understood in the frame of the own cosmovisions of native groups from different zones of Argentina. Those groups were going through a moment of strong transformations, but they did not resign their prominence in decision making which contributed to cultural reproduction. Indeed, they took an active part, either incorporating as rejecting, redefining, or abandoning customs, objects, and products within the unceasing social and historic dynamics. In this cultural frame, the appropriation of "peaches" and citrus turns these originally exotic fruits into identifying elements that contribute to the definition of the communities and the landscape where their daily life has place. Given 
that those environments can undergo changes and so their material nature frequently varies through time, these plants introduced in a relatively short period and with written record allow the researcher to understand and to design landscape domestication, as a multidimensional result of either physical, social, and symbolic environment $[108,109]$.

\section{Acknowledgments}

The authors especially thank the inhabitants of the areas in NEA and NWA for kindly sharing their knowledge and time. The authors are grateful to the Laboratorio de Botánica Sistemática y Etnobotánica (LABOCyE) FCA, UNJu, Laboratorio de Etnobotánica y Botánica Aplicada (LEBA) FCNyM, UNLP, the Instituto de Biología Subtropical (IBS) FacFor, UNaM, and CONICET for material and financial support. Our gratitude goes also to Guillermo Gil for advise in statistical analyses and to anonymous reviewers for improving the paper.

\section{References}

[1] A. Capparelli, N. Hilgert, A. Ladio et al., "Paisajes culturales de Argentina: pasado y presente desde las perspectivas etnobotánicas y paleobotánicas," Revista de la Asociación Argentina de Ecología del Paisaje, vol. 2, no. 2, pp. 67-79, 2011.

[2] J. Ochoa and A. Ladio, "Pasado y presente del uso de plantas silvestres con órganos de almacenamiento subterráneos comestibles en la Patagonia," Bonplandia, vol. 20, no. 2, pp. 265284, 2011.

[3] M. L. Pochettino, M. R. Martínez, and M. Crivos, "Landscape domestication among two mbyá-guaraní communities in Misiones, Argentina," in Ethnobiology and Biocultural Diversity, J. R. Stepp, F. S. Wyndham, and R. K. Zarger, Eds., pp. 696-704, University of Georgia Press, Athens, Ga, USA, 2002.

[4] A. Capparelli and R. A. Raffino, "Arqueoetnobotánica de El Shincal I: tallos finos, frutos y semillas," Tawantinsuyu, vol. 3, pp. 40-57, 1997.

[5] M. Giovannetti, "La conquista del noroeste argentino y los cultivos europeos," Fronteras de la Historia, no. 10, pp. 253-283, 2005.

[6] M. Giovannetti and V. Lema, "Cultivos introducidos por los europeos en el Shinkal de Quimivil: La presencia de los Hispano en la supervivencia ritual," in Entre Pasado Y Presente, A. Cetti, A. Re, D. Rindel, and P. Valeri, Eds., pp. 410-429, VI Jornadas de jóvenes investigadores en ciencias antropológicas, Instituto Nacional de Antropología y Pensamiento Latinoamericano, Buenos Aires, Argentina, 2005.

[7] V. S. Lema, Domesticación vegetal y grado de dependencia ser humano-planta en el desarrollo cultural Prehispánico del Noroeste argentino [Tesis doctoral (inédita)], Facultad de Ciencias Naturales y Museo, Universidad Nacional de La Plata, La Plata, Argentina, 2009.

[8] J. H. Galloway, "Sugar," in The Cambridge World History of Foods, K. F. Kiple and K. C. Ornelas, Eds., vol. 1, chapter II, pp. 437-449, Cambridge University Press, Cambridge, UK, 2000.

[9] A. Sepp, Relación de Viaje a las Misiones Jesuíticas, Edición crítica de W. Hoffmann. Tomo I. Ed. EUDEBA, 1971.

[10] J. García Paris, Intercambio y difusión de plantas de consumo entre el Nuevo y el Viejo mundo, Servicio de Extensión Agraria,
Ministerio de Agricultura, Pesca y Alimentación, Madrid, Spain, 1991.

[11] J. A. González, M. García-Barriusoy, and F. Amich, "Medicina tradicional en España y Argentina: comparación preliminar de algunas especies originarias de Europa," in Avances Sobre Plantas Medicinales Andinas, N. D. Vignale and M. L. Pochettino, Eds., chapter 7, pp. 245-268, RISAPRET/CYTED, San Salvador de Jujuy, Argentina, 2009.

[12] M. de la Puente y Olea, Los Trabajos Geográficos de la Casa de la Contratación, Escuela Tipográfica y Librería Salesianas, Sevilla, Spain, 1900.

[13] F. Paucke, Hacia allá y para acá (Una estada entre los indios mocobies 1749-1767, Universidad Nacional del Tucumán, Tucumán, Argentina, 1944, Traducción castellana por E. Wernicke. Tomo III, segunda parte.

[14] M. C. Vera de Flachs and C. Page, "Textos clásicos de medicina en la botica jesuítica del Paraguay," Cuadernos del Instituto Antonio de Nebrija, vol. 13, pp. 117-135, 2010.

[15] J. Morton, Fruits of Warm Climates, Florida Flair Books, Miami, Fla, USA, 1987.

[16] J. Dr. Duke's Phytochemical and Ethnobotanical Databases, http://www.ars-grin.gov/duke/.

[17] L. Sadori, E. Allevato, G. Bosi et al., "The introduction and diffusion of peach in ancient Italy," in Plants and Culture: Seeds of the Cultural Heritage of Europe, J. P. Morel and A. M. Mercuri, Eds., pp. 45-61, Centro Europeo per i Beni Culturali, Ravello, Italy, 2009.

[18] A. L. Cabrera, Regiones Fitogeografícas Argentinas, Enciclopedia Agricultura y Jardinería. Tomo II., ACME, 1976.

[19] R. Martínez-Crovetto, "Esquema fitogeográfico de la provincia de Misiones (República Argentina)," Bonplandia, vol. 1, no. 3, pp. 171-223, 1963.

[20] J. C. Chebez, Guía de las reservas naturales de la Argentina. Nordeste, Editorial Albatros, Buenos Aires, Argentina, 2005.

[21] L. J. Bartolomé and G. Schiavoni, Desarrollo y estudios rurales en Misiones, Ediciones CICCUS, Buenos Aires, Argentina, 2008.

[22] L. Cadogan, Cadogan, según Cadogan. Entrevista Diario La Tribuna, 9 de febrero de 1969, http://www.portalguarani .com/obras_autores_detalles.php?id_obras=17830.

[23] B. Susnik, Los aborígenes del Paraguay: Tomo II. Etnohistoria de los Guaraníes: época colonial, Museo Etnográfico "A. Barbero", Escuela Técnica Salesiana, Asunción, Paraguay, 1979-1980.

[24] M. Chase-Sardi, "El tekoha. Su organización social y los efectos negativos de la deforestación entre los Mbyá-guaraní," Suplemento Antropológico, vol. 24, no. 2, pp. 33-41, 1989.

[25] E. Schaden, Aspectos Fundamentales de la Cultura Guaraní, Centro de Estudios Antropológicos (CEADUC), Universidad Católica, “N.S. de la Asunción”, Asunción, Paraguay, 1998.

[26] G. Schiavoni, "Organización doméstica y apropiación de tierras fiscales en la Provincia de Misiones (Argentina)," Desarrollo Económico, vol. 34, pp. 595-608, 1995.

[27] G. Schiavoni, Colonos y ocupantes: parentesco, reciprocidad y diferenciación social en la frontera agraria de Misiones, Editorial Universitaria, Universidad Nacional de Misiones, Posadas, Argentine, 1998.

[28] G. Navarro and M. Maldonado, Geografía Ecológica de Bolivia, Vegetación y Ambientes Acuáticos, Editorial Centro de Ecología Difusión Simón I. Patiño, Santa Cruz, Calif, USA, 2002.

[29] G. Karasik, "Intercambio tradicional en la Puna Jujeña," Runa, vol. 14, pp. 51-91, 1984. 
[30] G. F. Scarpa and P. Arenas, "Especias y colorantes en la cocina tradicional de la Puna jujeña (Argentina)," Candollea, vol. 51, pp. 483-514, 1996.

[31] N. I. Hilgert and G. E. Gil, "Traditional andean agriculture and changing processes in the Zenta river basin, Salta, Northwestern Argentina," Darwiniana, vol. 43, no. 1-4, pp. 30-43, 2005.

[32] G. F. Torres, M. C. Bianchetti, and M. E. Santoni, "La dieta de los campesinos del Valle Calchaquí y de la Puna y sus determinantes culturales," Kallawaya Serie Monográfica, no. 1, p. $46,1985$.

[33] M. A. Albeck, Taller de Costa a Selva. Producción e Intercambio entre los pueblos agroalfareros de los Andes Centro Sur, Instituto Interdisciplinario Tilcara, Tilcara, Argentina, 1994.

[34] C. Troncoso, "El diseño de las estrategias de vida de los campesinos en Juella," in La Quebrada. Geografía, Historia y Ecología de la Quebrada de Humahuaca, C. Reboratti, Ed., pp. 139-160, Editorial La Colmena, Buenos Aires, Argentina, 2003.

[35] R. A. Raffino, J. D. Gobbo, and A. Iácona, "De Potosí y Tarija a la frontera Chiriguana," Folia Histórica del Nordeste, vol. 16, pp. 83-129, 2006.

[36] R. H. Bernard, Social Research Methods. Qualitative and Quantitative Approaches, Sage, Thousand Oaks, Calif, USA, 2000.

[37] U. P. Albuquerque, R. F. Paiva de Lucena, and L. V. F. Cruz da Cunha, Métodos e técnicas na pesquisa Etnobiológica y Etnoecológica, Nuppea, Recife, Brazil, 1st edition, 2010.

[38] W. Swingle, "The botany of Citrus and its wild relatives of the orange subfamily (Family Rutaceae, subfamily Aurantioideae)," in The Citrus Industry. History, Botany, and Breeding, H. Webber and L. Batchelor, Eds., pp. 129-474, University of California Press, Berkeley, Calif, USA, 1943.

[39] H. Webber, "Cultivated varieties of Citrus," in The Citrus Industry. History, Botany, and Breeding, $\mathrm{H}$. Webber and $\mathrm{L}$. Batchelor, Eds., pp. 475-668, University of California Press, Berkeley, Calif, USA, 1943.

[40] J. Palacios, Citricultura Moderna, Hemisferio Sur, Buenos Aires, Argentina, 1st edition, 1978.

[41] C. Anderson, "Variedades cultivadas en el área del Río Uruguay," in Manual para productores de naranja y mandarina de la región del Río Uruguay, A. Fabiani, R. Mika, L. Larocca, and C. Anderson, Eds., Diversificación Productiva, Manual Serie A, Nro. 2, pp. 63-92, INTA, Concordia, Canada, 1996.

[42] G. Delucchi, "Sinopsis de las especies de Rosaceae adventicias: subfamilia Prunoideae," Bonplandia, vol. 20, pp. 73-94, 2011.

[43] D. Rivera Núñez, C. Obón de Castro, S. Ríos Ruiz et al., Las variedades tradicionales de frutales de la Cuenca del Río Segura. Catálogo Etnobotánico (1): frutos secos, oleaginosos, frutales de hueso, almendros y frutales de pepita, Servicio de Publicaciones, Universidad de Murcia, Murcia, Spain, 1997.

[44] D. X. Zhang and D. J. Mabberley, "Citrus," in Flora of China, Z. Y. Wu, P. H. Raven, and D. Y. Hong, Eds., pp. 90-96, China and Missouri Botanical Garden Press, St. Louis, Mo, USA, 2008.

[45] D. Mabberley, "A classification for edible Citrus (Rutaceae)," Telopea, vol. 7, pp. 167-172, 1997.

[46] D. Mabberley, Plant-Book. A Portable Dictionary of Plants, Their Classification and Uses, Cambridge University Press, Cambridge, UK, 3rd edition, 2008.

[47] B. Á. Arias and L. Ramón-Laca, "Pharmacological properties of citrus and their ancient and medieval uses in the Mediterranean region," Journal of Ethnopharmacology, vol. 97, no. 1, pp. 89-95, 2005.
[48] B. de las Casas, Historia de las Indias, Tomo II. Edición del Marqués de la Fuensanta del Valle y D. José Sancho Rayon Imprenta de Miguel Ginesta, Madrid, Spain, 1875.

[49] J. de Acosta, Historia natural y moral de las Indias, Impreso en Casa de Juan León, Sevilla, Spain, 1590.

[50] R. Carbonell, Estrategias de desarrollo rural en los pueblos guaranies (1609-176), Antoni Bosch, Sociedad Estatal Quinto Centenario, Instituto de Estudios Fiscales \& Instituto de Cooperación Iberoamericana, Barcelona, Spain, 1992.

[51] L. Gálvez, Guaraníes y jesuitas. De la Tierra sin Mal al Paraíso, Editorial Sudamericana, Buenos Aires, Argentina, 1995.

[52] P. de Montenegro, Materia Medica Misionera, Edición digital Biblioteca Virtual del Paraguay, 1945.

[53] J. Cardiel, Breve relación de las misiones del Paraguay, Secretaría de Cultura de la Nación y Ed. Teoria, Buenos Aires, Argentina, 1994, Prólogo de E. Maeder.

[54] M. Bertoni, La civilización guaraní, Parte III. Etnografía. Conocimiento, 1927, Imprenta y Edición "Ex Sylvis", Puerto Bertoni.

[55] F. J. Brabo, Colección de documentos relaticos á la expulsión de los jesuitas de la República Argentina y del Paraguay, Establecimiento Tipográfico de J. M. Pérez, Madrid, Spain, 1872.

[56] R. Lista, El territorio de las Misiones, Imprenta "La Universidad" de J. N. Klingelfuss, Buenos Aires, Argentina, 1883.

[57] E. L. Holmberg, "Viaje a misiones," Boletín de la Academia Nacional de Ciencias en Córdoba, vol. 10, pp. 252-288, 1887.

[58] V. Gambón, A través de las misiones guaraníticas, Ángel Estrada y Cía, Buenos Aires, Argentina, 1904

[59] J. B. Ambrosetti, Primer y segundo viaje a Misiones por Juan Bautista Ambrosetti. Comentado por J. C. Chebez y B. Gasparri, Editorial Albatros, Fundación de Historia Natural Félix de Azara,, Buenos Aires, Argentina, 2008.

[60] J. B. Ambrosetti, Tercer viaje a Misiones por Juan Bautista Ambrosetti, Editorial Albatros, Fundación de Historia Natural Félix de Azara, Buenos Aires, Argentina, 2008, Comentado por J. C. Chebez y B. Gasparri.

[61] L. Depypere, P. Chaerle, K. V. Mijnsbrugge, and P. Goetghebeur, "Stony endocarp dimension and shape variation in Prunus section Prunus," Annals of Botany, vol. 100, no. 7, pp. 1585-1597, 2007.

[62] P. Burger, J.-F. Terral, M.-P. Ruas, S. Ivorra, and S. Picq, "Assessing past agrobiodiversity of Prunus avium L. (Rosaceae): a morphometric approach focussed on the stones from the archaeological site Hôtel-Dieu (16th century, Tours, France)," Vegetation History and Archaeobotany, vol. 20, no. 5, pp. 447458, 2011.

[63] J. R. Báez, "Breves apuntes sobre la migración de las plantas agrícolas Euro-Indianas en el momento del descubrimiento," Lilloa, vol. 18, pp. 311-360, 1949.

[64] J. R. Báez, "La primera colonia agrohispana en el Tucumán (Siglo XVI)," Revista Argentina de Agronomía, vol. 14, no. 2, pp. 85-93, 1947.

[65] A. Capparelli, V. Lema, and M. Giovanetti, "Introducción y dispersión de bienes de Viejo mundo: posibles rutas de ingreso a la provincia de Catamarca," Memorias del Tercer Congreso de Historia de Catamarca: arqueología, cultura, educación y geografía humana. pp. 85-105, Bazán, 2007.

[66] E. Tandeter, "Conquista y colonización," in Historia Económica de América Latina, problemas y procesos, E. Tandeter and J. C. Korol, Eds., pp. 21-57, Fondo de Cultura Económica, Buenos Aires, Argentina, 1998. 
[67] A. M. Lorandi, "El servicio personal como agente de desestructuración en el Tucumán colonial," Revista Andina, vol. 6, no. 1, pp. 135-173, 1988.

[68] A, Capparelli, M. Giovannetti, and V. Lema, "Primera evidencia de arqueológica de cultivos europeos (trigo, cebada y duraznos) y de semillas de algodón en el NOA: su significación a través del registro del Shincal de Quimivil," in Paleoetnobotánica del Cono Sur: estudios de casos y propuestas metodológicas, B. Marconetto, N. Oliszewsky, and P. Babot, Eds., pp. 25-48, Museo de antropología-Facultad de Filosofía y Humanidades, Universidad Nacional de Córdoba, Córdoba, Spain, 2007.

[69] P. Font Quer, Plantas medicinales, el Dioscórides renovado, Editorial LABOR, Barcelona, Spain, 11th edition, 1988.

[70] S. Castroviejo, Flora Ibérica. Plantas vasculares de la Península Ibérica, e Islas Baleares, vol. VI ROSACEAE of F. Muñoz Garmendia and C. Navarro, Eds., Real Jardín Botánico, C.S.I.C., Madrid, Spain, 1998.

[71] L. Manfred, Siete mil recetas botánicas a base de mil trescientas plantas medicinales, Editorial Kier, Buenos Aires, Argentina, 1947.

[72] C. Burmeister, Memoria sobre el territorio de Misiones, Ministerio de Agricultura de la República Argentina. Impr., Litogr. y Encuad. De J. Peuser, Buenos Aires, Argentina, 1899.

[73] J. Hieronymus, "Plantae diaphoricae florae argentinae ó revista sistemática de las plantas medicinales, alimenticias ó de alguna otra utilidad y de las venenosas, que son indígenas de la República Argentina ó que, originarias de otros países se cultivan ó se crían espontáneamente en ella," Boletín de la Academia Nacional de Ciencias en Córdoba, vol. 4, no. 3, pp. 199-598, 1882.

[74] J. Kumamoto, R. W. Scora, H. W. Lawton, and W. A. Clerx, "Mystery of the forbidden fruit: Historical epilogue on the origin of the grapefruit, Citrus paradisi (Rutaceae)," Economic Botany, vol. 41, no. 1, pp. 97-107, 1987.

[75] Citrus Pages, http://users.kymp.net/citruspages/home.html.

[76] M. C. Gallero and E. M. Krautstofl, "Proceso de poblamiento y migraciones en la provincia de Misiones, Argentina (18811970)," Avá, vol. 16, pp. 245-264.

[77] H. Webber, "History and development of the Citrus industry'”, in The Citrus Industry. History, Botany, and Breeding, $\mathrm{H}$. Webber and L. Batchelor, Eds., pp. 1-40, University of California Press, Berkeley, Calif, USA, 1st edition, 1943.

[78] J. Palacios, Citricultura Moderna, Hemisferio Sur, Buenos Aires, Argentina, 1978.

[79] A. Banfi, "Difusión de buenas variedades cítricas," IDIA, vol. 90-92, p. 102, 1954.

[80] A. Banfi and H. Beñatena, "Nuevas variedades en la colección de citrus," IDIA, vol. 90-92, pp. 101-102, 1954.

[81] Compañía Tabacalera de Misiones, http://www.cooptabmis .com/citrusespanol.html.

[82] M. N. Seo and C. Xifreda, "Rutaceae," in Flora Fanerogámica Argentina, A. M. Anton and F. O. Zuloaga, Eds., vol. 106, pp. 1-22, 2008.

[83] P. C. Stampella, G. Delucchi, and M. L. Pochettino, "Naturalización e identidad del "limón mandarina", Citrus $\times$ taitensis (Rutaceae, Aurantioideae) en la Argentina," Boletín de la Sociedad Argentina de Botánica, vol. 48, no. 1, pp. 161-169, 2013.

[84] J. S. Storni, Hortus Guaranenesis. Flora, Universidad Nacional de Tucumán, Imprenta y Litografía de Miguel Violetto, Tucumán, Argentina, 1944.
[85] L. Cadogán, “Diccionarios Mbya-Guaraní-castellano”, Biblioteca Paraguaya de Antropología vol. XVII. Fundación L. Cadogán. CEADUC-CEPAG, Asunción, Paraguay, 1992.

[86] D. A. Lambaré and M. L. Pochettino, "Diversidad local y prácticas agrícolas asociadas al cultivo tradicional de duraznos Prunus persica (ROSACEAE), en el Noroeste de Argentina," Darwiniana, vol. 50, no. 2, pp. 174-186, 2012.

[87] N. I. Hilgert, "Plants used in home medicine in the Zenta River basin, Northwest Argentina," Journal of Ethnopharmacology, vol. 76, no. 1, pp. 11-34, 2001.

[88] N. I. Hilgert, S. Reyes, and G. Schmeda-Hirschmann, "Alkaline substances used with coca (Erythroxylum coca, Erythroxylaceae) leaf insalivation in northwestern Argentina," Economic Botany, vol. 55, no. 2, pp. 325-329, 2001.

[89] N. I. Hilgert, "Plant species used during insalivation of "coca" (Erythroxylum coca var. coca, Erythroxylaceae) leaves," Darwiniana, vol. 38, no. 3-4, pp. 241-252, 2000.

[90] B. Nagaraju, S. C. Anand, N. Ahmed, J. N. Narendra Sharath Chandra, F. Ahmed, and G. V. Padmavathi, "Antiulcer activity of aqueous extract of Citrus medica linn. fruit against ethanolinduced ulcer in rats," Advances in Biological Research, vol. 6, no. 1, pp. 24-29, 2012.

[91] F. Conforti, G. A. Statti, R. Tundis, M. R. Loizzo, and F. Menichini, "In vitro activities of Citrus medica L. cv. Diamante (Diamante citron) relevant to treatment of diabetes and Alzheimer's disease," Phytotherapy Research, vol. 21, no. 5, pp. 427-433, 2007.

[92] G. B. Bairagi, A. O. Kabra, and R. J. Mandade, "Anthelmintic activity of Citrus medica L. leaves in indian adult earthworm," International Journal of PharmTech Research, vol. 3, no. 2, pp. 664-667, 2011.

[93] N. E. Sandoval-Montemayor, A. García, E. Elizondo-Treviño, E. Garza-González, L. Alvarez, and M. del Rayo CamachoCorona, "Chemical composition of hexane extract of Citrus aurantifolia and anti-Mycobacterium tuberculosis activity of some of its constituents," Molecules, vol. 17, no. 9, pp. 11173-11184, 2012.

[94] F. Spadaro, R. Costa, C. Circosta, and F. Occhiuto, "Volatile composition and biological activity of key lime Citrus aurantifolia essential oil," Natural Product Communication, vol. 7, no. 11, pp. 1523-1526, 2012.

[95] L. M. Lopes Campêlo, C. Gonçalves E Sá, A. A. C. de Almeida et al., "Sedative, anxiolytic and antidepressant activities of Citrus limon (Burn) essential oil in mice," Pharmazie, vol. 66, no. 8, pp. 623-627, 2011.

[96] M. J. Dhanavade, C. B. Jalkute, J. S. Ghosh, and K. D. Sonawane, "Study Antimicrobial Activity of Lemon (Citrus lemon L.) Peel Extract," British Journal of Pharmacology and Toxicology, vol. 2, no. 3, pp. 119-122, 2011.

[97] H. S. Parmar and A. Kar, "Antiperoxidative, antithyroidal, antihyperglycemic and cardioprotective role of Citrus sinensis peel extract in male mice," Phytotherapy Research, vol. 22, no. 6, pp. 791-795, 2008.

[98] A. T. Rajarajan, V. G. Vijayasree, W. Kenichi, S. Vijaya Kumar, G. Narasimman, and S. Sadish Kumar, "Anthelmintic and antimicrobial properties of peels of Citrus sinensis," Pharmacologyonline, vol. 1, pp. 363-368, 2009.

[99] J. A. Saonere Suryawanshi, "An overview of Citrus aurantium used in treatment of various diseases," African Journal of Plant Science, vol. 5, no. 7, pp. 390-395, 2011.

[100] M. I. R. Carvalho-Freitas and M. Costa, "Anxiolytic and sedative effects of extracts and essential oil from Citrus aurantium L," 
Biological and Pharmaceutical Bulletin, vol. 25, no. 12, pp. 16291633, 2002.

[101] S. Husain Shahnaz, M. Ali, and B. Prasad Panda, "Influence of volatile constituents of fruit peels of Citrus reticulata Blanco on clinically isolated pathogenic microorganisms under In-vitro," Asian Pacific Journal of Tropical Biomedicine, vol. 2, no. 3, pp. 1299-1302, 2012.

[102] J. A. Díaz-Juárez, F. A. Tenorio-Lapez, G. Zarco-Olvera, L. D. Valle-Mondragan, J. C. Torres-Narváez, and G. PastelínHernández, "Effect of Citrus paradisi extract and juice on arterial pressure both in vitro and in vivo," Phytotherapy Research, vol. 23, no. 7, pp. 948-954, 2009.

[103] V. Gupta, P. Bansal, J. Niazi, and G. Kaur, "Anti-anxiety activity of Citrus paradisi var. star ruby extracts," International Journal of PharmTech Research, vol. 2, no. 3, pp. 1655-1657, 2010.

[104] A. A. Adeneye, "Hypoglycemic and hypolipidemic effects of methanol seed extract of Citrus paradisi Macfad (Rutaceae) in alloxan-induced diabetic Wistar rats," Nigerian Quarterly Journal of Hospital Medicine, vol. 18, no. 4, pp. 211-215, 2008.

[105] T.-Y. Shin, S.-B. Park, J.-S. Yoo et al., "Anti-allergic inflammatory activity of the fruit of Prunus persica: Role of calcium and NF$\kappa \mathrm{B}$," Food and Chemical Toxicology, vol. 48, no. 10, pp. 27972802, 2010.

[106] A. H. Gilani, N. Aziz, S. M. Ali, and M. Saeed, "Pharmacological basis for the use of peach leaves in constipation," Journal of Ethnopharmacology, vol. 73, no. 1-2, pp. 87-93, 2000.

[107] Y. H. Kim, H. E. Yang, B. K. Park, M. Y. Heo, B. K. Jo, and H. P. Kim, "The extract of the flowers of Prunus persica, a new cosmetic ingredient, protects against solar ultraviolet-induced skin damage in vivo," Journal of Cosmetic Science, vol. 53, no. 1, pp. 27-34, 2002.

[108] K. Seeland, Ed., Nature is culture: indigenous knowledge and socio-cultural aspects of trees and forests in non-European cultures, Intermediate Technology Publications, London, UK, 1997.

[109] C. Vitri, "La ruta de Diego de Almagro en el territorio argentino: un aporte desde la perspectiva de los caminos prehispánicos," Revista escuela de historia, Facultad de Humanidades Universidad Nacional de Salta, vol. 1, año 6, no. 6, 2007. 


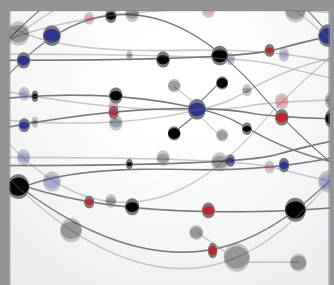

The Scientific World Journal
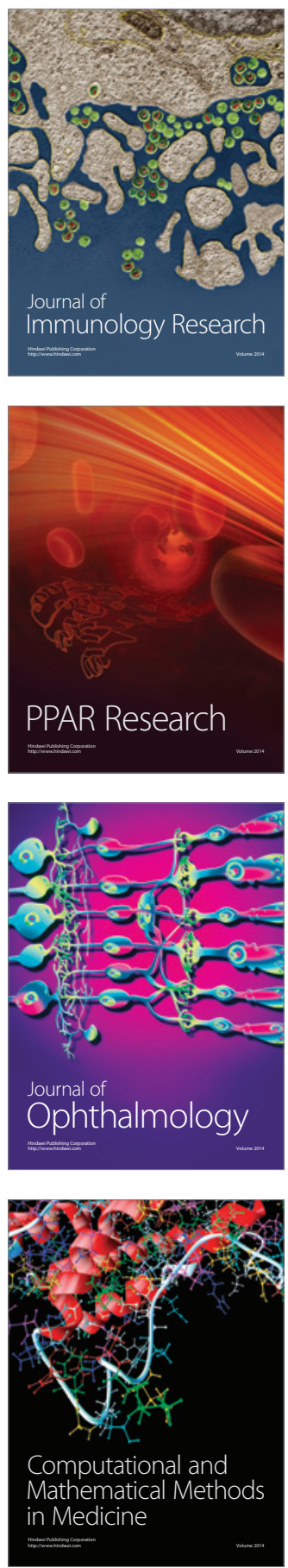

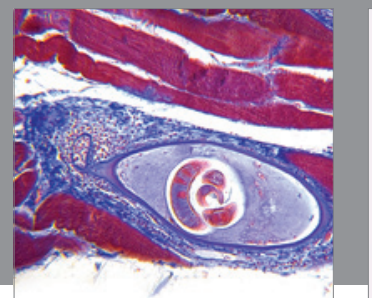

Gastroenterology

Research and Practice
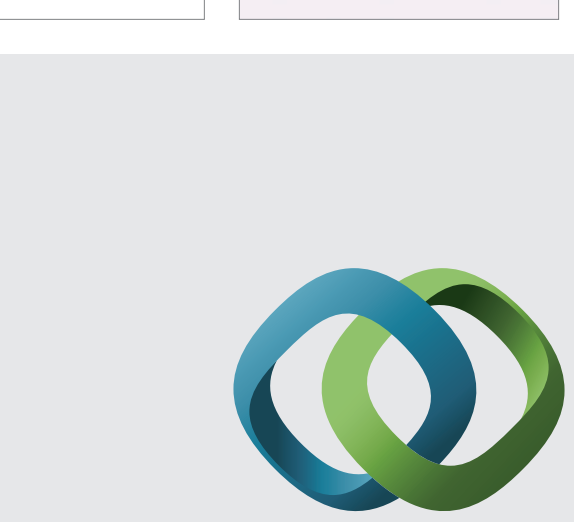

\section{Hindawi}

Submit your manuscripts at

http://www.hindawi.com
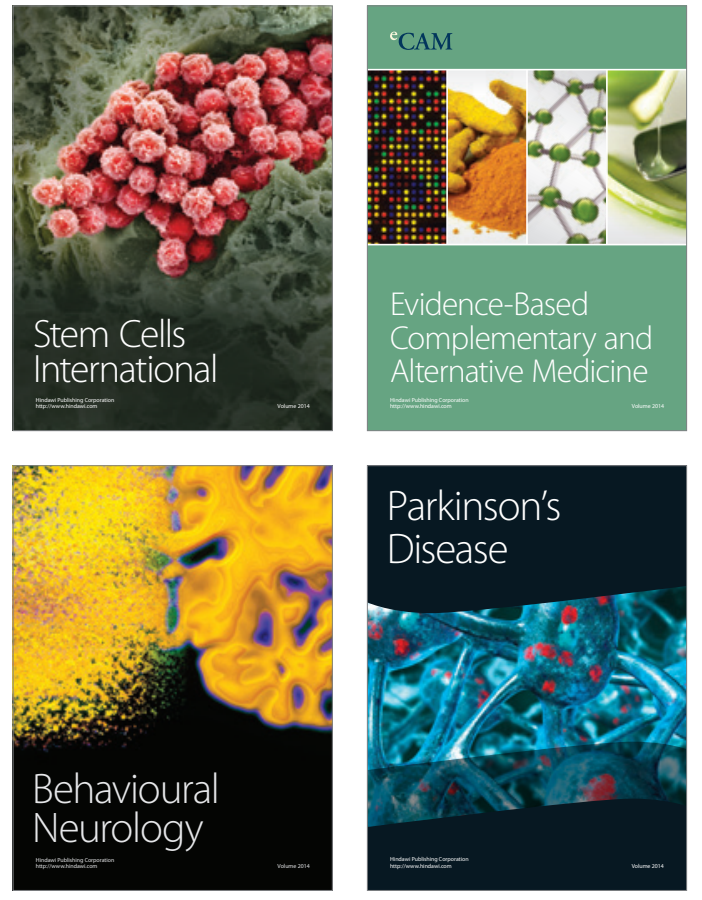
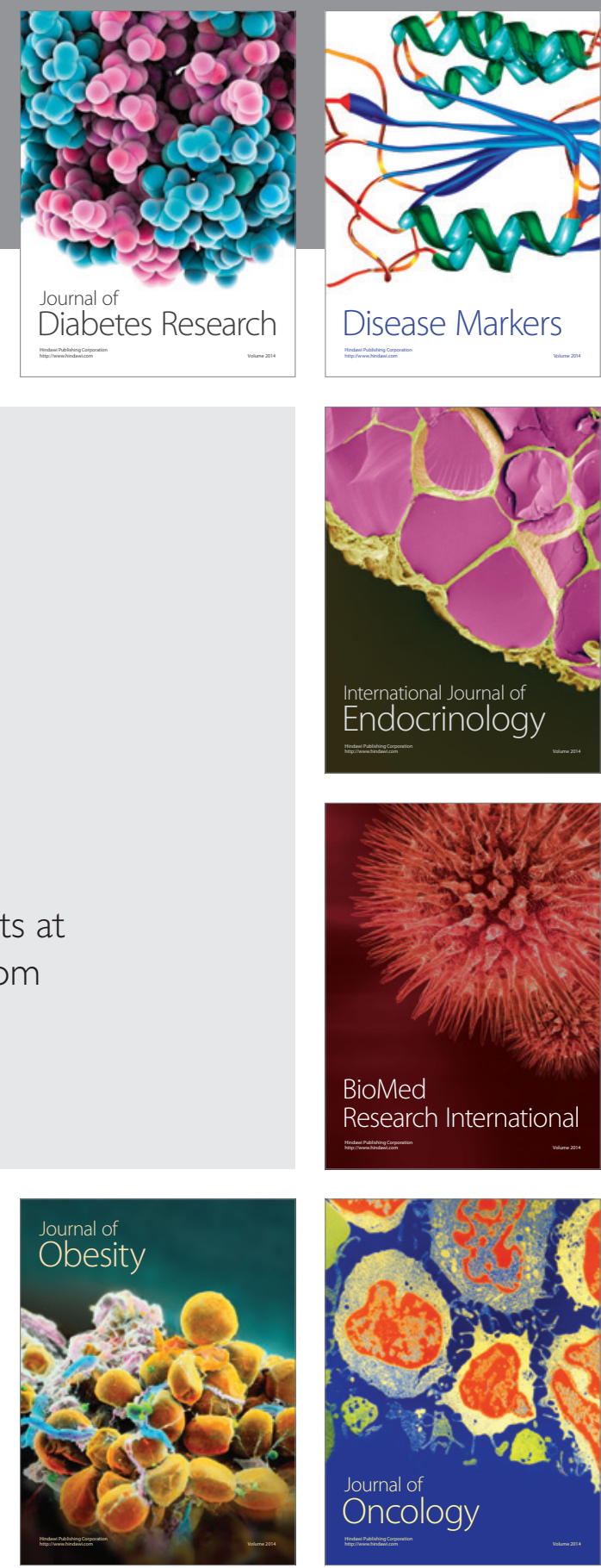

Disease Markers
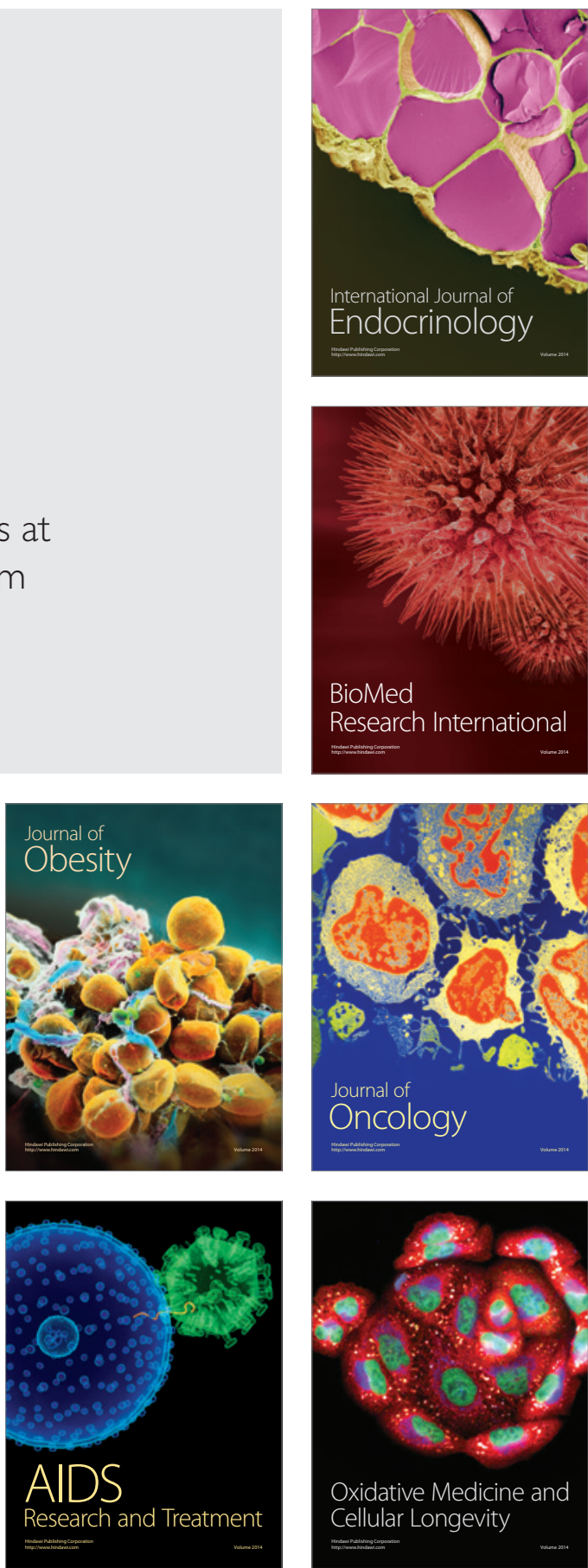